\title{
The 2011 eruptive activity of Shinmoedake volcano, Kirishimayama, Kyushu, Japan-Overview of activity and Volcanic Alert Level of the Japan Meteorological Agency-
}

\author{
Koji Kato $^{1,2 *}$ and Hitoshi Yamasato ${ }^{2}$ \\ ${ }^{1}$ Fukuoka District Meteorological Observatory, Japan Meteorological Agency, 1-2-36, Ohori, Chuo, Fukuoka 810-0052, Japan \\ ${ }^{2}$ Seismological and Volcanological Department, Japan Meteorological Agency, 1-3-4, Otemachi, Chiyoda, Tokyo 100-8122, Japan
}

(Received November 9, 2012; Revised May 8, 2013; Accepted May 13, 2013; Online published July 8, 2013)

\begin{abstract}
Following several years of small phreatic eruption events, Shinmoedake volcano in Kyushu, Japan, began a new phase of activity on 19 January 2011. The eruption commenced with a small phreatomagmatic event followed by subplinian events on 26 and 27 January. Lava emerged as a dome in the summit crater on 27 January and filled the crater until the beginning of February. During the subplinian events and lava dome growth, deflation of the deep magma chamber was observed by tiltmeters and GPS. Eruptive activity began to decrease in March 2011 and no eruptive event occurred after the 7 September 2011 event. In response to the eruption, the Japan Meteorological Agency (JMA) issued warnings repeatedly to prepare local people and infrastructures around Shinmoedake. JMA did not raise the Volcanic Alert Level before the first subplinian event, because of a lack of clear precursory signals. We conclude that a large amount of magma moved in the shallow Shinmoedake plumbing system for a short time, based on a number of geophysical observations. It is important to detect magma movement and understand eruptive phenomena quickly in order to mitigate risks of volcanic hazards.
\end{abstract}

Key words: Shinmoedake, Kirishimayama, Volcanic Alert Level.

\section{Introduction}

Kirishimayama, located in southern Kyushu, Japan, is a group of more than 20 basaltic-andesite volcanoes (Fig. 1). Kirishimayama is one of famous sightseeing areas in Kyushu, and has many hot spring resorts. Kirishimayama has more than 10 volcanoes which were active during the last 22,000 years, including very active volcanoes such as Shinmoedake, Ohachi and Iwoyama with historical eruption records. Shinmoedake (1,421 $\mathrm{m}$ of peak altitude) is a stratovolcano which is located at the center of Kirishimayama. Before the 2011 eruption, magmatic eruption occurred in 1716-1717, when subplinian events occurred, being associated with pyroclastic flows and mudflows. Imura and Kobayashi (1991) showed that the eruption progressed from phreatic to magmatic phases in the 1716-1717 eruption. After this eruption, Shinmoedake experienced repeated small eruptions before 2011 .

After repeated phreatic eruption events in 2008 and 2010, Shinmoedake began magmatic eruptions in January 2011. Following a small phreatomagmatic event on 19 January 2011, the volcanic activity began with a subplinian event on 26 January. Three subplinian events, effusion of lava inside the summit crater and frequent vulcanian events took

\footnotetext{
*Now at Seismological and Volcanological Department, Japan Meteorological Agency, 1-3-4, Otemachi, Chiyoda, Tokyo 100-8122, Japan.
}

Copyright (C) The Society of Geomagnetism and Earth, Planetary and Space Sciences (SGEPSS); The Seismological Society of Japan; The Volcanological Society of Japan; The Geodetic Society of Japan; The Japanese Society for Planetary Sciences; TERRAPUB.

doi:10.5047/eps.2013.05.009 place. Here, we define "vulcanian event" as an eruption event accompanied by a strong shock wave and an explosion earthquake. During the subplinian events and effusion of lava, deflation of the deep magma chamber was observed by tiltmeters and GPS.

Over the course of the 2011 eruption, falling of a large amount of tephra and shockwaves damaged people's lives and houses around Shinmoedake. To manage risks from volcanic eruption events of the 2011 eruption at Shinmoedake, the Japan Meteorological Agency (JMA) issued "volcanic information" to announce risks and restrictions on approaching to the volcanic areas for the public and others. JMA adopted a system of "Volcanic Alert Level" for active volcanoes in December 2007 (Ikeuchi and Yokota, 2007). This system was applied also to Shinmoedake in 2007, and JMA tried the risk management during the 2011 eruption by operating this system.

In this paper, we provide an overview of the 2011 eruption with the geophysical monitoring results mainly, and discuss the effect and problem of Volcanic Alert Level in the 2011 eruption at Shinmoedake.

\section{Volcano Monitoring at Shinmoedake Volcano}

The Fukuoka District Meteorological Observatory (FDMO) and the Kagoshima Local Meteorological Observatory (KLMO) of JMA jointly monitor the activity of Shinmoedake Volcano with a real-time network consisting of seismometers, low-frequency (LF) microphones, tiltmeters, GPS stations and cameras. This monitoring is carried out in cooperation with the University of Tokyo, Kyushu University, National Research Institute for Earth Science and 


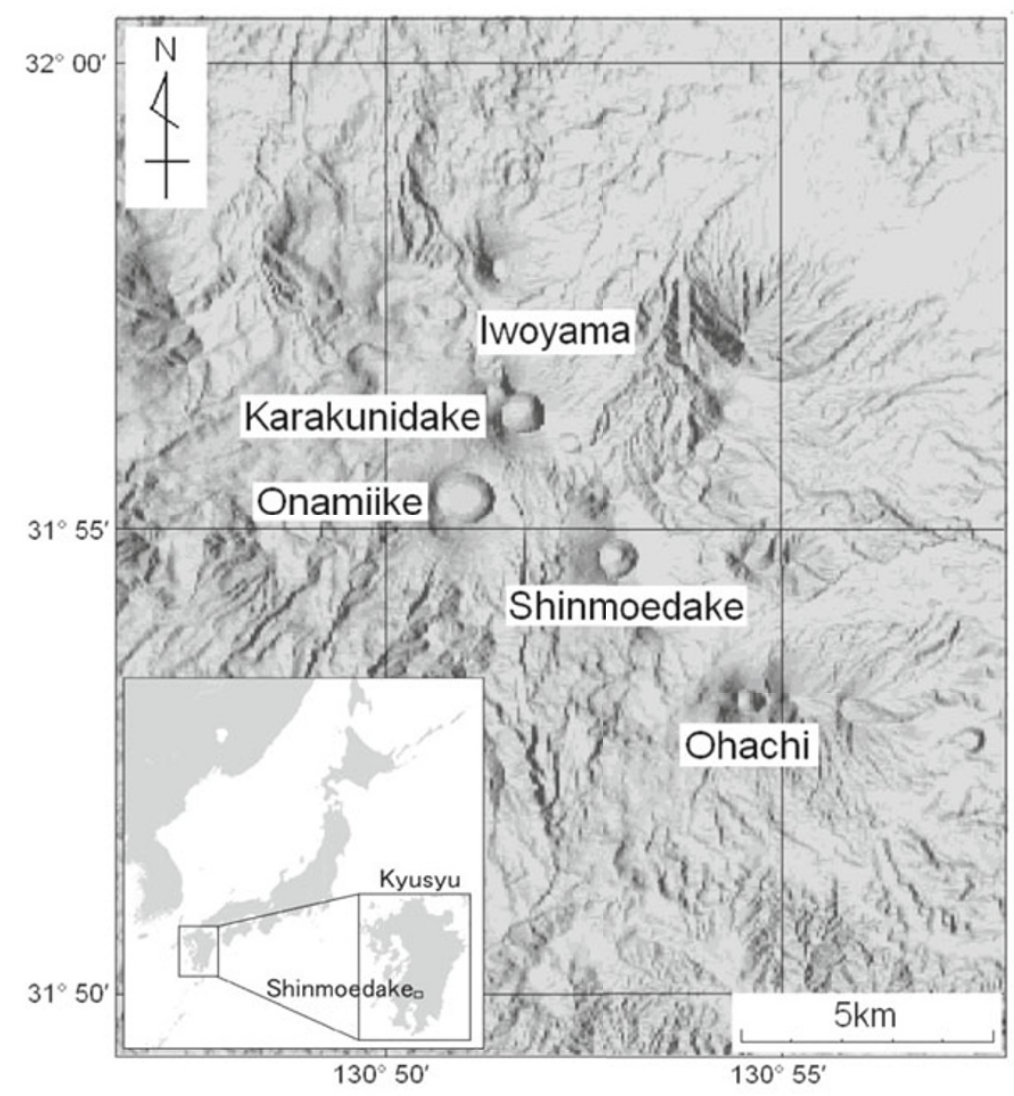

Fig. 1. Topographic map of Kirishimayama.

Disaster Prevention, Geospatial Information Authority of Japan and Kagoshima Prefecture. Figure 2 shows locations of the observation stations and instrument sites for Kirishimayama. Monitoring data are telemetered to FDMO and KLMO via telephone lines and radio. Before the 2011 eruption, JMA had installed 14 seismometers, 3 LF microphones, 6 tiltmeters, 11 GPS stations and 4 cameras in Kirishimayama in cooperation with other organizations. When the 2011 eruption started, JMA installed 6 additional seismometers, 3 LF microphones, 4 tiltmeters and 2 cameras to strengthen monitoring of Shinmoedake in cooperation with other organizations. JMA conducted periodical areal observations by helicopters in cooperation with the Ministry of Defense, the Ministry of Land, Infrastructure, Transport and Tourism, and Kagoshima and Miyazaki prefectures. In addition, volcanic gas $\left(\mathrm{SO}_{2}\right)$ measurement and field survey of eruption products were also carried out jointly with researchers of universities and Geological Survey of Japan.

\section{Prior to the 2011 Magmatic Eruption}

After small phreatic eruptions in 1991, Shinmoedake had been calm until the summer of 2008. On 19 August 2008, the number of volcanic earthquakes beneath Shinmoedake began to increase (Fig. 3). A small phreatic event occurred on 22 August. Although the ash plume was not identified due to bad weather, volcanic ash fell over the northeastern area up to about $20 \mathrm{~km}$ from the volcano. The eruption event continued for several hours. The total mass of tephra of this event was estimated as $2.0 \times 10^{5} \mathrm{t}$ (Geshi et al., 2010). JMA carried out an aerial survey of the crater in cooperation with the Kyushu Regional Development Bureau, of the Ministry of Land, Infrastructure, Transportation and Tourism on 24 August, and observed new fissures of 300$400 \mathrm{~m}$ long, trending E-W, on the western outer-slope of the crater. The seismic activity rapidly declined after 22 August and volcanic plume activity gradually declined toward January 2009 (Fig. 3).

Both campaign and continuous GPS observations by JMA detected local ground deformation changes at Shinmoedake summit area before the 22 August 2008 eruption event. Inflation of the summit area was observed during 2005 to 2007, while deflation of the same area began in 2007 and continued until 2009, and the pressure sources for the inflation and deflation were identical, about 500-600 m below the crater with the volume changes of the inflation of about $1 \times 10^{5} \mathrm{~m}^{3}$ (Takagi et al., submitted). More extensive ground deformation observed by Geospatial Information Authority of Japan showed a source of increasing pressure at $6-10 \mathrm{~km}$ depth, several kilometers northwest of Shinmoedake from the end of 2009 (Imakiire and Oowaki, 2011). The volume change for this source from the end of 2009 to January 2011 was calculated as $1.5 \times 10^{7} \mathrm{~m}^{3}$ (Imakiire and Oowaki, 2011). Only after 2011 Shinmoedake eruption started, was it realized that this extensive deformation was caused by magma accumulation in the magma chamber that was located not just under the Shinmoedake crater but northwest of Shinmoedake. 

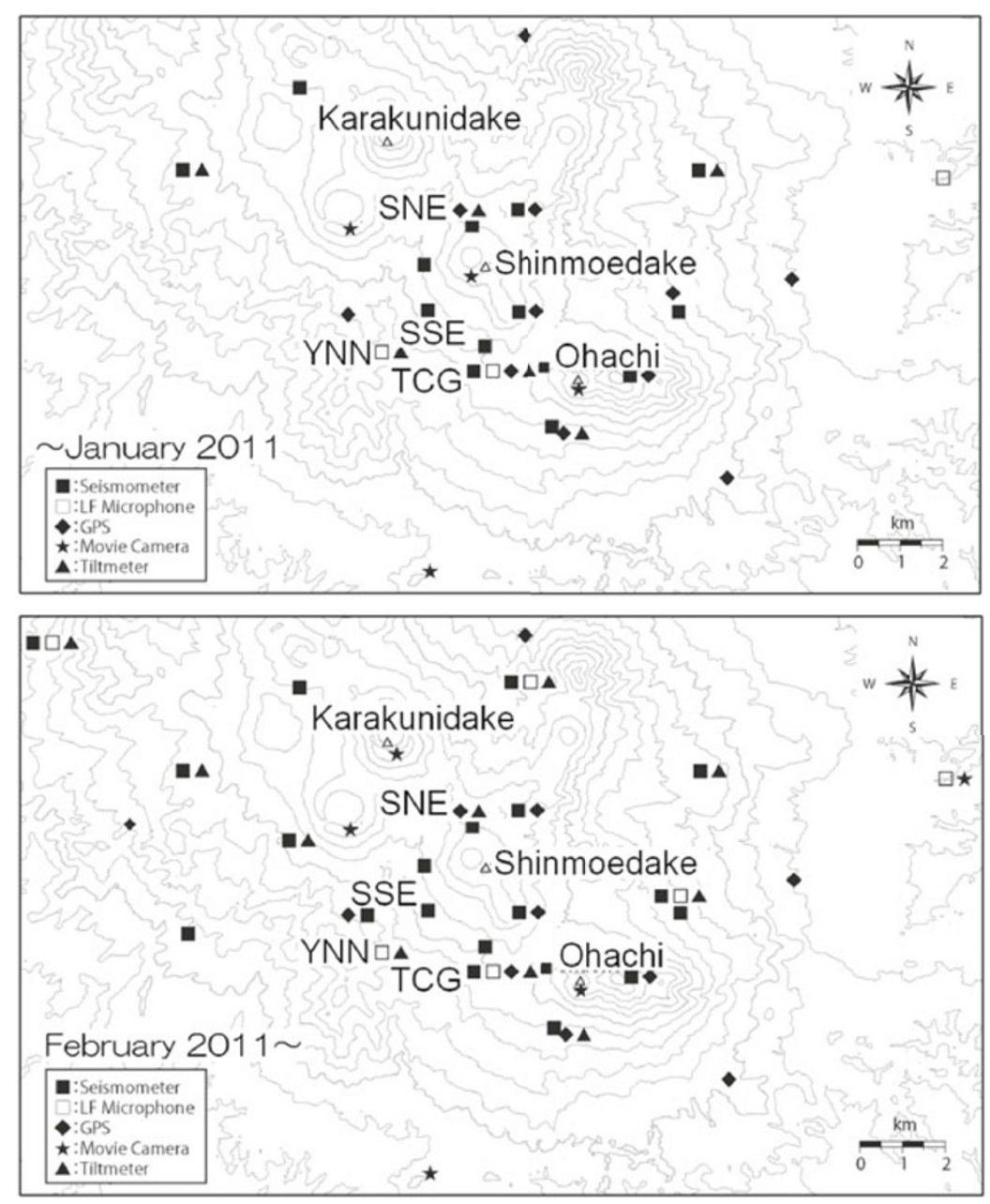

Fig. 2. Location of monitoring and observation stations (include stations installed by other organizations). Close Squares are seismometers, open squares are LF microphones, diamonds are GPS stations, stars are movie cameras, and triangles are tiltmeters. Top panel shows network station density before January 2011. Bottom panel shows additional stations installed following the onset of the 2011 eruption.

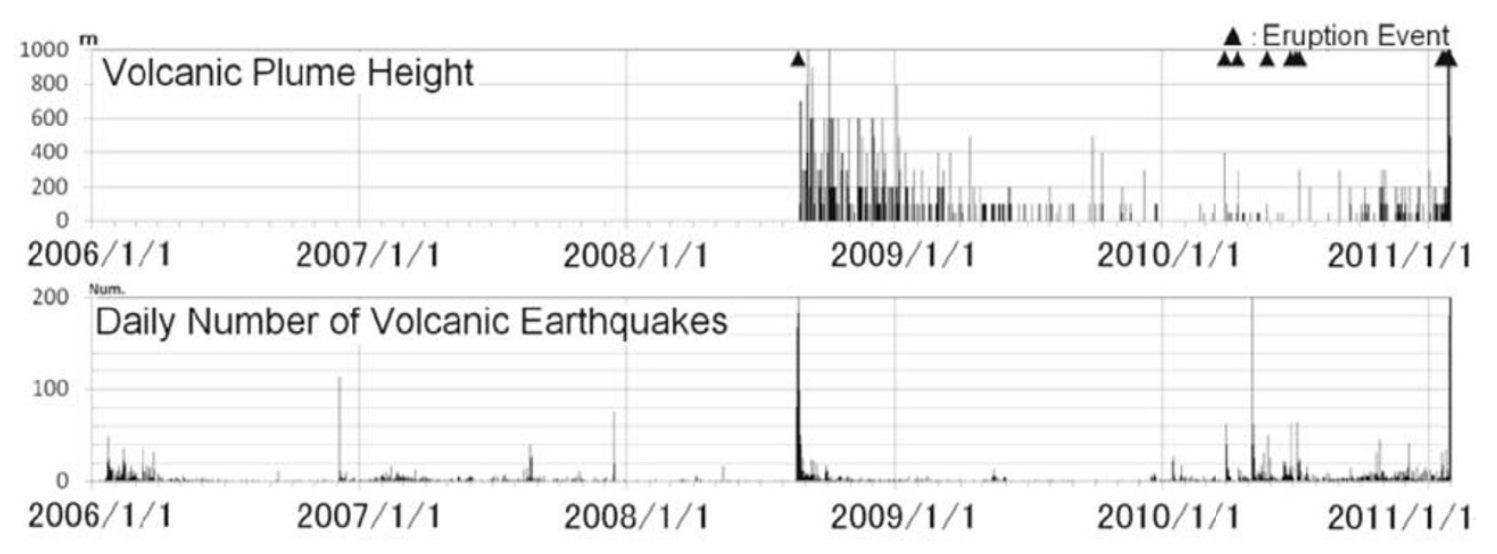

Fig. 3. (Top) Height of passive volcanic plume and eruptions include phreatic, phreatomagmatic, and magmatic eruption (triangles) at Shinmoedake from January 2006 to January 2011. There was no plume at all prior to late 2008. (Bottom) Daily number of volcanic earthquakes (all types).

On 30 March 2010, a small phreatic eruption event occurred at Shinmoedake. The ash plume rising $400 \mathrm{~m}$ above the crater and a very minor ashfall covering inside the crater and the western slope and flank of the crater was observed by an aerial survey on the same day; this was carried out in cooperation with Kyushu Regional Development Bureau, Kagoshima and Miyazaki prefectures. The tephra mass of this eruption was estimated as a few ten tons by Kobayashi et al. (2011). Similar small phreatic eruption events occurred at Shinmoedake on 17 April, 27 May, 27 and 28 June, and 5 and 10 July (Table 1). The mass of tephra from the 27 May event was estimated as approximately a few hundred tons (Kobayashi et al., 2011). Ash of the 30 March event was mainly composed of altered material, and that of 
Table 1. List of 2008-2012 main eruptions of Shinmoedake.

\begin{tabular}{|c|c|c|c|c|c|}
\hline No. & date & $\begin{array}{c}\text { Plume } \\
\text { height }(\mathrm{m})\end{array}$ & $\begin{array}{c}\text { Max Seismic } \\
\text { Amp. } \\
(\mu \mathrm{m} / \mathrm{sec})(\mathrm{SSE})\end{array}$ & $\begin{array}{c}\text { Max Air } \\
\text { wave Amp. } \\
(\mathrm{Pa})(\mathrm{YNN})\end{array}$ & Remarks \\
\hline 1 & $2008 / 08 / 2216: 34$ & unknown & 23.6 & unknown & Phreatic \\
\hline 2 & 2010/03/30 08:00 & unknown & 15.3 & - & Phreatic \\
\hline 3 & 2010/04/17 01:14 & unknown & 5.4 & 0.7 & Phreatic \\
\hline 4 & $2010 / 05 / 27$ 15:37 & $>100$ & 50.7 & 2.6 & Phreatic \\
\hline 5 & 2010/06/27 01:35 & unknown & 25.6 & 1.1 & Phreatic \\
\hline 6 & $2010 / 06 / 28$ 16:02 & unknown & 31.5 & 0.7 & Phreatic \\
\hline 7 & 2010/07/05 11:03 & & unknown & unknown & Phreatic \\
\hline 8 & 2010/07/10 05:28 & $>300$ & 101.8 & 4.4 & Phreatic \\
\hline 9 & $2011 / 01 / 1901: 27$ & unknown & 69.6 & 1.4 & Phretomagmatic \\
\hline 10 & $2011 / 01 / 22$ 07:30 & 200 & unknown & - & Phretomagmatic \\
\hline 11 & $2011 / 01 / 2607: 31$ & 200 & unknown & - & Phretomagmatic \\
\hline 12 & 2011/01/26 14:49 & 3000 & 403.5 & 1.6 & \\
\hline 13 & $2011 / 01 / 26$ 17:05 & 3000 & 52.0 & 9.5 & $\begin{array}{c}\text { Subplinian } \\
7000 \mathrm{~m} * \text { (Shimbori et al. submitted) }\end{array}$ \\
\hline 14 & $2011 / 01 / 2618: 50$ & 2000 & unknown & - & \\
\hline 15 & 2011/01/27 02:20 & 2000 & 98.9 & 9.1 & $\begin{array}{c}\text { Subplinian } \\
7000 \mathrm{~m} * \text { (Shimbori et al. submitted })\end{array}$ \\
\hline 16 & $2011 / 01 / 2715: 41$ & $>2500$ & 3327.0 & 39.7 & Vulcanian \\
\hline 17 & $2011 / 01 / 2717: 20$ & 3000 & 156.9 & 8.5 & $\begin{array}{c}\text { Subplinian } \\
7000 \mathrm{~m} *(\text { Shimbori et al. submitted })\end{array}$ \\
\hline 18 & $2011 / 01 / 2812: 47$ & $>1000$ & 773.0 & 81.8 & Vulcanian \\
\hline 19 & $2011 / 01 / 3013: 57$ & unknown & 829.0 & 21.7 & Vulcanian \\
\hline 20 & $2011 / 02 / 0107: 54$ & 2000 & 3767.0 & 458.4 & Vulcanian \\
\hline 21 & 2011/02/01 23:19 & $>2000$ & 3541.0 & 185.5 & Vulcanian \\
\hline 22 & $2011 / 02 / 0205: 25$ & $>2000$ & 3408.0 & 299.6 & Vulcanian \\
\hline 23 & $2011 / 02 / 0210: 47$ & $>500$ & 1501.0 & 86.5 & Vulcanian \\
\hline 24 & $2011 / 02 / 0215: 53$ & 3000 & 5306.0 & 72.4 & Vulcanian \\
\hline 25 & 2011/02/03 08:09 & 1500 & 963.0 & 26.0 & Vulcanian \\
\hline 26 & 2011/02/04 09:42 & 3000 & 290.0 & 15.7 & \\
\hline 27 & 2011/02/06 03:16 & $>2000$ & 249.4 & 14.9 & \\
\hline 28 & 2011/02/07 06:07 & 1500 & 1313.8 & 16.4 & \\
\hline 29 & 2011/02/07 18:09 & 1200 & 70.8 & - & \\
\hline 30 & 2011/02/11 11:36 & 2500 & 3410.0 & 244.3 & Vulcanian \\
\hline 31 & 2011/02/14 05:07 & unknown & 16517.0 & 332.1 & Vulcanian \\
\hline 32 & $2011 / 02 / 18$ 18:16 & 3000 & 2479.0 & 31.4 & Vulcanian \\
\hline 33 & 2011/02/24 03:38 & $>600$ & 214.4 & 0.4 & \\
\hline 34 & 2011/02/28 17:08 & 300 & 33.4 & 1.3 & \\
\hline 35 & 2011/03/01 19:23 & unknown & 2485.0 & 69.6 & Vulcanian \\
\hline 36 & 2011/03/03 18:08 & $>1500$ & 140.6 & 5.5 & \\
\hline 37 & $2011 / 03 / 0802: 50$ & 1000 & 122.4 & 6.4 & \\
\hline 38 & $2011 / 03 / 13$ 17:45 & 4000 & 161.1 & 7.2 & \\
\hline 39 & 2011/03/23 08:23 & 1000 & 91.7 & 1.4 & \\
\hline 40 & 2011/03/29 03:33 & 500 & 17.1 & 0.1 & \\
\hline 41 & $2011 / 04 / 03$ 08:41 & 3000 & 135.7 & 2.7 & \\
\hline 42 & 2011/04/09 01:06 & unknown & 69.4 & 0.7 & \\
\hline 43 & $2011 / 04 / 18$ 19:22 & 2000 & 64.6 & 3.3 & \\
\hline 44 & 2011/08/31 02:43 & 500 & 79.1 & 0.9 & \\
\hline 45 & 2011/09/07 06:00 & 300 & 1.6 & - & \\
\hline
\end{tabular}

※ Shimbori et al. (submitted) estimated ash plume height by weather radars. $7000 \mathrm{~m}$ in remarks are ash plume height estimated by Shimbori et al. (submitted).

the 27 May 2010 event included a very small amount of glass scoria, suggestive of juvenile material (Suzuki et al., 2013). Other samples from these phreatic events were not collected.

After the eruption event on 10 July 2010, the number of volcanic earthquakes gradually decreased. However, at the beginning of October 2010, seismicity increased slightly and the plume activity became somewhat more vigorous (Fig. 3).

During the period from 27 May to 10 July, the volcanic activity in the crater was monitored by a video camera installed on the crater rim. Based on the comparison of the video footage with seismic and tilt records (Fig. 4), it is clearly indicated that tremor event associated with inflation at the shallow part beneath the crater began several minutes before the eruption event. The inflation turned into deflation immediately after ash was emitted (Kato et al., 2010).

We evaluated the relative magnitudes of individual phreatic eruption events by comparing seismic and infrasonic signals. Table 1 summarizes the amplitudes of volcanic tremors and infrasonic signals for these events. The infrasonic signals associated with the eruption event in 2008 could not be identified as they were masked by wind noise. Their amplitudes are similar for all phreatic eruption events, 

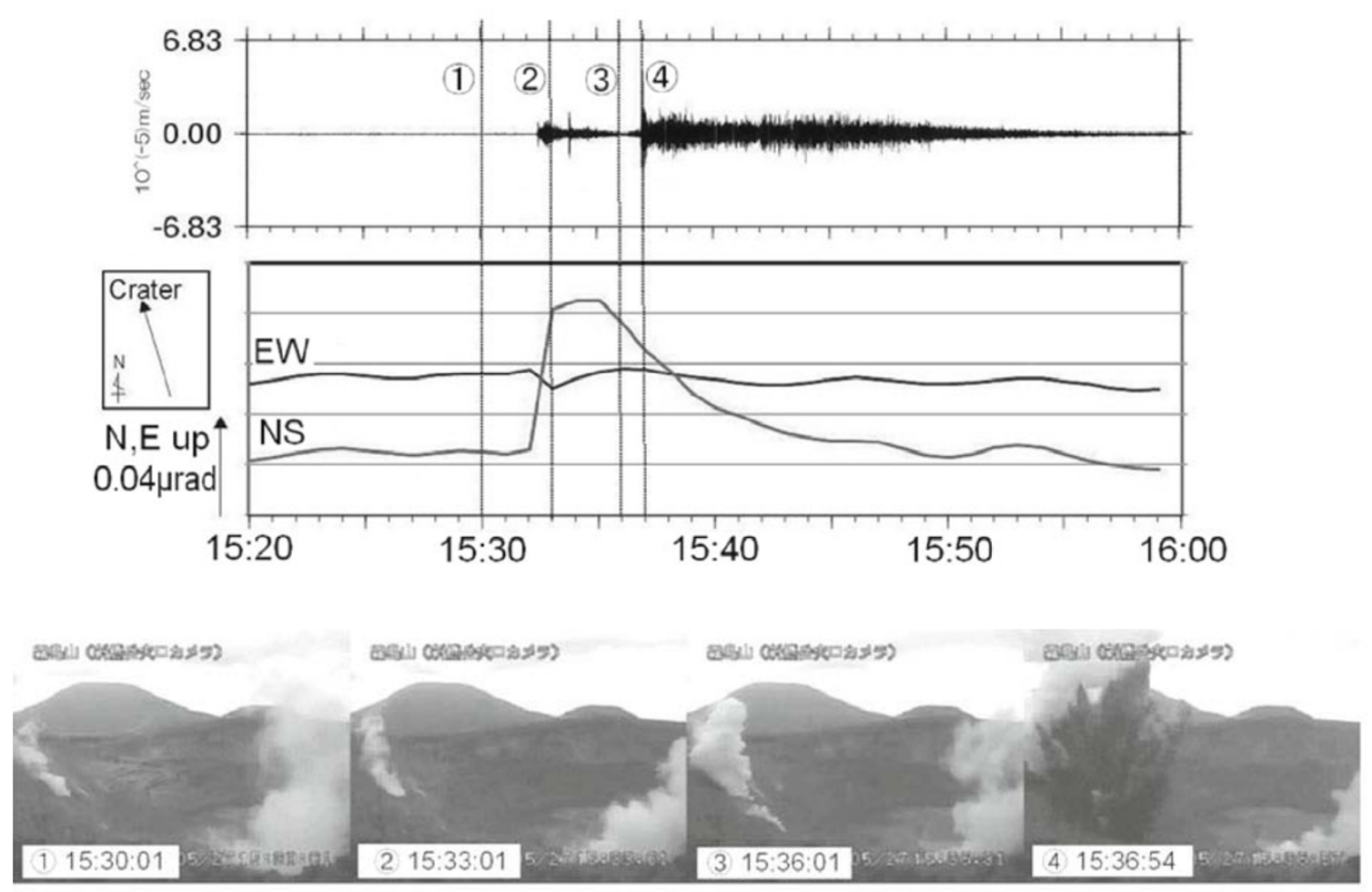

Fig. 4. Velocity seismogram of vertical component at station SSE (see Fig. 1), tilt record at TCG (see Fig. 1) and visual images of 27 May 2010 event. The number on seismograms corresponds to the number on visual images.

and are about one order of magnitude smaller than those for the magmatic eruption events which started in January 2011.

\section{Overview of the 2011 Eruption-Time Se- quence}

At 01:27 on 19 January 2011 (JST used throughout this paper), a small eruption event occurred. Although an ash plume of this eruption was not witnessed due to bad weather, ash fall was observed at Miyakonojo and Nichinan cities, Miyazaki Prefecture, located about $60 \mathrm{~km}$ southeast of Shinmoedake. The ash emission continued for about 2 hours. The amplitude of volcanic tremor and infrasonic wave for this event were similar to those of phreatic eruption events in 2008 and 2010 (Table 1). However, according to Geshi et al. (2011) and Suzuki et al. (2013), the ash of this eruption event contained pumiceous particles about $10 \%$ in volume. Therefore, it is considered that this eruption was phreatomagmatic and new magma had reached to a shallow level under the Shinmoedake crater.

On 26 January, the eruptive activity became vigorous; an ash plume continuously rose about $200 \mathrm{~m}$ above the crater from 07:31, and the amount of the plume increased suddenly at 14:49 and the plume reached over 3,000 $\mathrm{m}$ above the crater. Shimbori et al. (submitted) estimated the plume height during $17: 11$ to $17: 19$ as 7,000 $\mathrm{m}$ above the crater based on the ground-based weather radar and meteorological satellite data. A large amount of ash and pumice fell downwind; small pumices of 7-8 $\mathrm{cm}$ in diameter were found in Kirishima City, about $3 \mathrm{~km}$ from Shinmoedake. This was a subplinian event, clearly suggesting that the activity of Shinmoedake had entered into a magmatic stage.
Two other subplinian events occurred within the next 24 hours. Weather radars and meteorological satellite of JMA detected volcanic ash clouds from these events. Coinciding with these events, very large amplitudes of volcanic tremors and infrasonic signals were observed (Table 1; Fig. 5). JMA conducted ejecta surveys on 27 January 2011, and found that ash fall deposits were several centimeters thick at about $3 \mathrm{~km}$ southeast of the crater. These subplinian events continuously emitted large amounts of ash which caused delays in air traffic. Nakada et al. (2013) estimated that the amount of tephra produced by these three subplinian events at about $0.66-1.2 \times 10^{7} \mathrm{~m}^{3}$ in dense rock equivalent. Small pyroclastic flow and surges accompanied these subplinian events (Nakada et al., 2013). Large and sudden tilt changes were recorded simultaneously with the subplinian events (Fig. 5), suggesting sudden deflations of the magma chamber located northwest of Shinmoedake. Kozono et al. (2013) calculated the magma fluxes for three subplinian events at about 450 $563,592-741$ and $481-602 \mathrm{~m}^{3} / \mathrm{s}$, respectively.

Prior to the onset of the subplinian event on 26 January, volcanic earthquakes did not increase in frequency and no obvious direct precursor was observed. However, a small inflation was observed by tiltmeters on the stations near the crater several hours before the 19 January and 26 January events (Fig. 6).

A small mound of lava was observed in the middle of the crater during an overflight of Shinmoedake crater on 28 January 2011 (Nakada et al., 2013). Ando et al. (2011) noted a small lava dome of approximately $50 \mathrm{~m}$ across on 27 January. A large lava dome with diameter approximately $600 \mathrm{~m}$ by 30 January was confirmed by the synthetic aperture radar (SAR) images from the Advanced Land Observing Satellite 


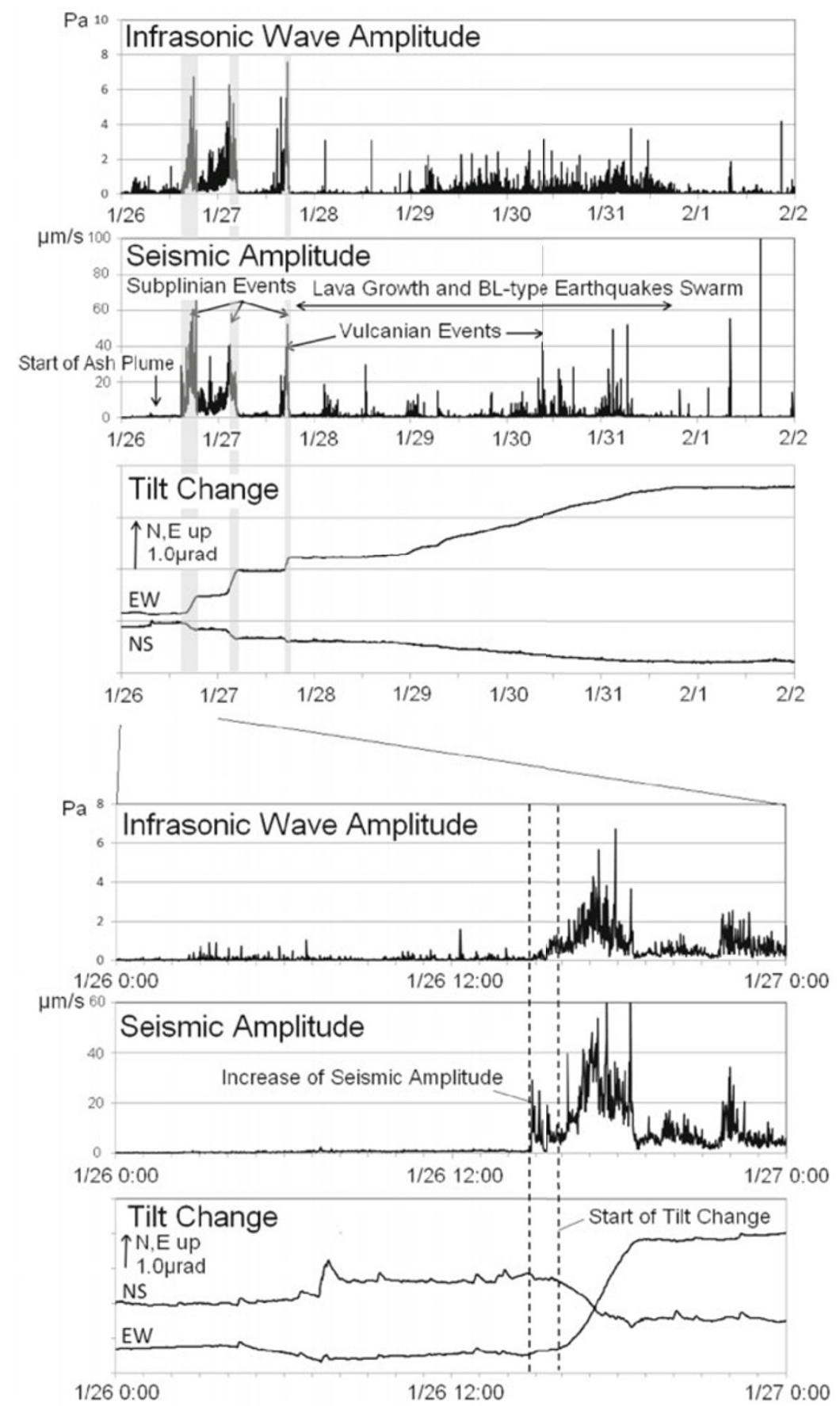

Fig. 5. One second averaged amplitude of infrasonic wave at station YNN and velocity vertical component seismogram (one second averaged amplitude) at station SSE and tilt record at station TCG associated with subplinian eruption events and subsequent lava growth. Gray zones indicate three subplinian eruption events each lasting several hours. Tilt records are corrected to remove tidal effects by BAYTAP-G (Ishiguro and Tamura, 1985). Lower panel shows an expanded view of January 26-27 at the start of magmatic eruptive activity.

(ALOS) and by JMA on 31 January (Ando et al., 2011). Based on photo analysis (Fig. 7), it is considered that lava effusion stopped in early February and the final volume of the lava dome was estimated at $1.4 \times 10^{7} \mathrm{~m}^{3}$ (Sasaki et al., 2011).

During the lava dome growth, a tilt change showing down of the NWW side at TCG station (see Fig. 2) was observed, suggesting the deflation of the deep magma chamber. The total volume of deflation associated with subplinian events and subsequent lava effusion was estimated as about $10^{7} \mathrm{~m}^{3}$ (Kozono et al., 2013). This volume roughly equals to the ejecta volume in magmatic eruption during 26-31 January. It may suggest that magma moved from the deep magma chamber northwest of Shinmoedake directly to the crater without stopping beneath the crater.

The lava effusion during the period from 27 January to the beginning of February was associated with frequent vulcanian events, low frequency earthquakes and harmonic tremor events (Fig. 8). We classified volcanic earthquakes into five types, referring to Iguchi (1994) at Sakurajima which is similar andesitic volcano with Shinmoedake. 


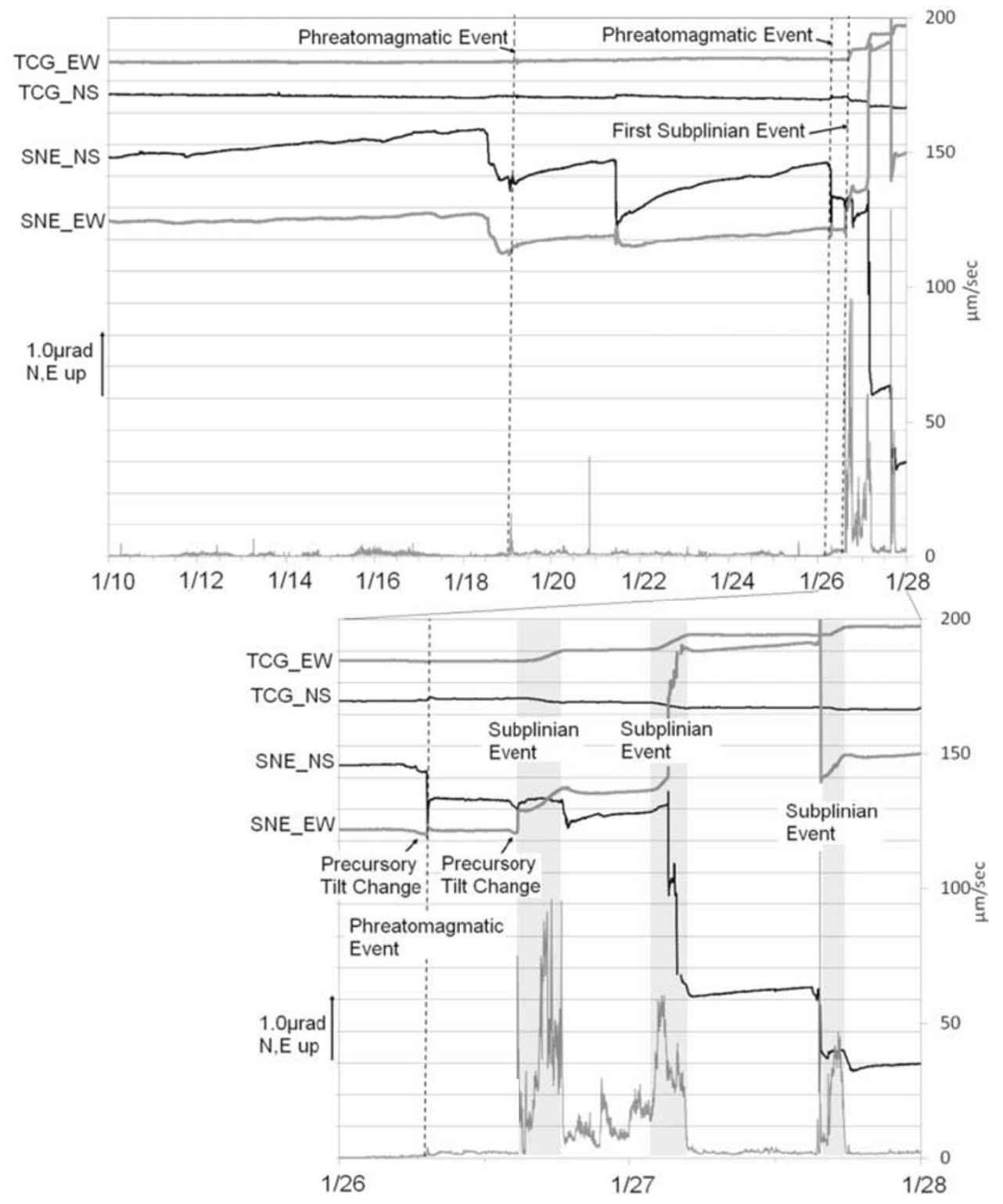

Fig. 6. Tilt records at TCG and SNE and one minute averaged seismic velocity amplitude at TCG (vertical component) associated with subplinian eruption events. Gray zones indicate three subplinian eruption events lasting several hours. Steps at SNE after onset of subplinian eruption events are noises caused by large seismic signal. Tilt records are corrected to remove tidal effects by BAYTAP-G (Ishiguro and Tamura, 1985). Lower panel shows an expanded view of January 26-27 at the start of magmatic eruptive activity.

A-type: volcano-tectonic earthquake with clear $P$ and $S$ phases and the dominant frequency is relatively high. BH-type: low frequency earthquake with unclear $S$ phase and the dominant frequency more than about $3 \mathrm{~Hz}$.

BL-type: low frequency earthquake with unclear $S$ phase and the dominant frequency less than about $3 \mathrm{~Hz}$.

EX-type: explosion-quake associated with vulcanian event.

BP-type: harmonic quake with unclear $P$ and $S$ phases, characterized by regular peaks of spectra, and composed of fundamental frequency and its overtone.

At 15:41 on 27 January, the first vulcanian event occurred between the second and third subplinian events. Since then, 13 vulcanian events occurred until 1 March 2011 (Table 1).
The vulcanian event at 07:54, 1 February was most energetic, accompanied by the largest shockwave (Table 1) whose maximum amplitude was $458 \mathrm{~Pa}$ at YNN station (see Fig. 2), about $3 \mathrm{~km}$ away from the Shinmoedake crater. The shockwave broke glass windows in houses at Kirishima City, located several kilometers from the crater. Ballistic projectiles reached up to $3.2 \mathrm{~km}$ from the crater (Maeno et al., 2013).

From the beginning of February 2011, eruptive activity including vulcanian events occurred intermittently (Fig. 8). A vulcanian event on 14 February emitted pumice fragments with diameter of $1.5-5 \mathrm{~cm}$ that fell about $16 \mathrm{~km} \mathrm{NE}$ from Shinmoedake, which broke windshields there. In the 13 March vulcanian event, the ash plume rose as high as $4,000 \mathrm{~m}$ above the carter and pumice fragments with $1-4 \mathrm{~cm}$ in diameter fell about $9 \mathrm{~km}$ SE from Shinmoedake. Further eruption events which occurred after February 2011 sent 

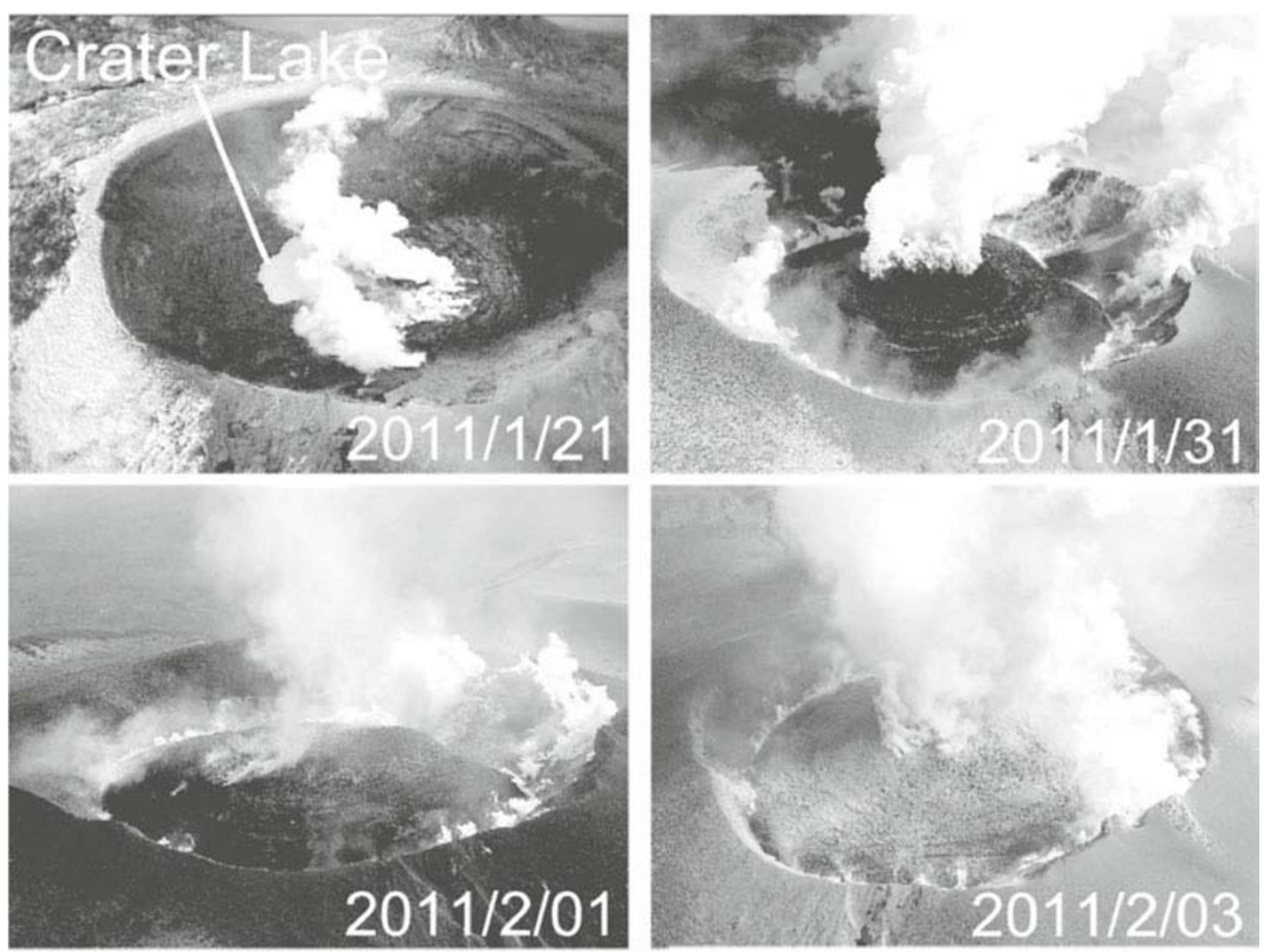

Fig. 7. State of the Shinmoedake crater observed by aerial observation in late January and early February 2011. Prior to extrusion of a lava dome, an acidic cold lake filled the bottom of the crater.

pumiceous lapilli several kilometers downwind, although the frequency and magnitude of eruption events gradually had decreased with time. No eruption event occurred after the 7 September 2011 event. The number of volcanic earthquakes then decreased, and the seismicity declined by May 2012, returning to the level before the 2011 eruptive activity.

Based on GPS measurements by Geospatial Information Authority of Japan, the deep magma chamber which deflated during the subplinian events and lava effusion resumed its inflation in the beginning of February and continued until December 2011 (Fig. 9). Extension of the baselines surrounding Shinmoedake almost stopped by January 2012, and contraction was observed in May 2012.

In addition to seismic and geodetic monitoring, JMA periodically measured $\mathrm{SO}_{2}$ flux from the crater using a compact UV spectrometer (COMPUSS) (Mori et al., 2007). During the subplinian events, $\mathrm{SO}_{2}$ flux exceeded 10,000 tons/day (Fig. 8). On 28 January when lava was found inside the crater, the flux was more than 40,000 tons/day (Mori et al., 2011). The flux decreased to the levels of several hundred tons/day in mid-February when eruption events were repeated, under 100 tons/day in March 2012, and few tons/day after May 2012.

\section{Magnitude and Precursors of the 2011 Shin- moedake Eruption Events}

Here we compare the magnitude of the subplinian events on 26 January with those at other volcanoes. McNutt (1994) showed an empirical relationship between the tremor amplitudes and plume heights. We used the reduced displacement for the 26 January event to evaluate the plume height based on McNutt (1994). The reduced displacement was calculated according to the definition of Aki and Koyanagi (1981). We found that the 26 January event follows McNutt's (1994) relationship, and that the subplinian event was equivalent to that of the 1983 Pavlof eruption and smaller than that of the 1977 Usu eruption (Fig. 10(a)). Furthermore, Fig. 10(b) shows the relationship between seismic and infrasonic amplitudes, associated with recent eruptions at several volcanoes in Japan. In this figure, seismic and infrasonic amplitudes are represented by those at a distance of $3 \mathrm{~km}$ and $5 \mathrm{~km}$ from the active crater, respectively. For continuous ash-producing eruption events, volcanic tremor and infrasonic amplitudes are well correlated in terms of scaling to eruption magnitudes (Yamasato et al., 2008). The result shows that phreatic eruption events at Shinmoedake in 2010 are almost similar to those of other phreatic eruption events in Japan. On the other hand, the subplinian eruption event was about an order of magnitude larger than phreatic eruption events at Shinmoedake and similar to the largest eruption event at Miyakejima in 2000.

As mentioned above, no remarkable precursory phenomena were observed just before the first subplinian event on 26 January. However, after the beginning of February, tilt changes accompanied by $\mathrm{BH}$-type earthquake swarms were often observed for about 60 hours before the events (Fig. 11). The tilt changes showed slight uplifts of southwest direction at the SNE station, the northwest direction at YNN and the north direction at TCG, respectively (Fig. 12). The amounts of tilt changes were 0.001-0.2 $\mu$ radian at TCG. Immediately after the eruption occurred, the tilt changed reversely, suggesting deflation, and $\mathrm{BH}-$ type earthquakes decreased gradually (Fig. 11). Kato et al. 


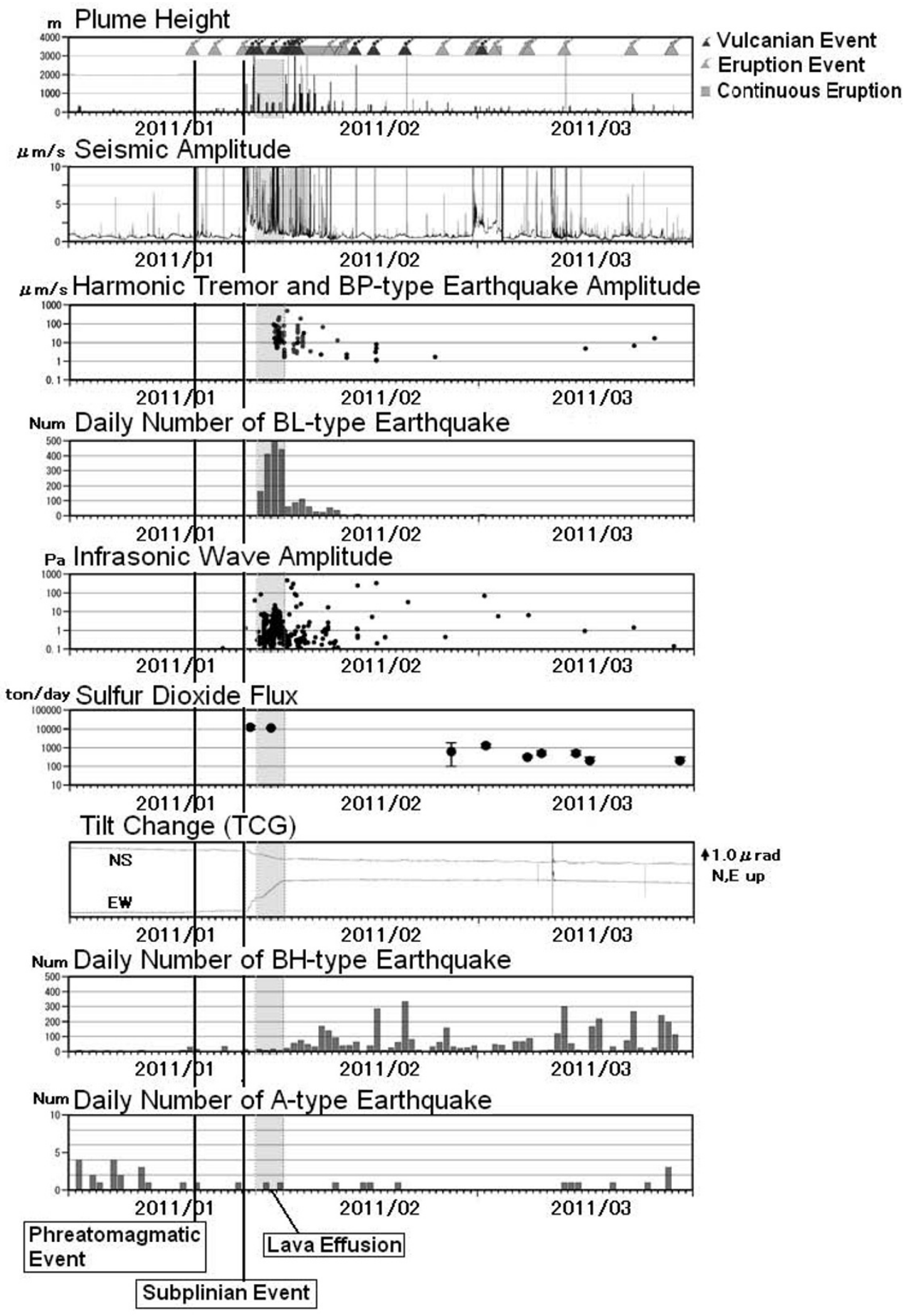

Fig. 8. Summary of volcano monitoring data for Shinmoedake from January 2011 to March 2011. Gray zones indicate lava emission. Eruption events include phreatic, phreatomagmatic, and magmatic eruption, but exclude vulcanian eruption events. BP-type earthquake is harmonic earthquake, BL-type earthquake is low frequency earthquake, BH-type earthquake is shallow volcano-tectonic earthquake, and A-type earthquake is deep volcano-tectonic earthquake.

(2011) estimated the source parameters of these tilt changes by using a dike model (Okada, 1992). The modeled dike is set beneath the southwestern flank of Shinmoedake at depth of about $1 \mathrm{~km}$ (Fig. 12). The volume of inflation by this modeled dike intrusion was estimated about several $10^{4} \mathrm{~m}^{3}$. This result suggests that magma intruded in a dike beneath southwestern flank of the crater from the deep magma chamber just prior to individual eruption events.

\section{Volcanic Alert Level of JMA}

JMA officially started issuing Volcanic Warnings and Volcanic Forecasts on 1 December 2007 in order to mitigate risks and impacts from volcanic phenomena in Japan. When the warning statements are issued, JMA also issues the level of alert for regions around the volcano, regarding to volcanic hazards. The Volcanic Alert Levels consists of five levels, depending on the target areas or regions, defined in distances from the volcanic centers or craters, and the 

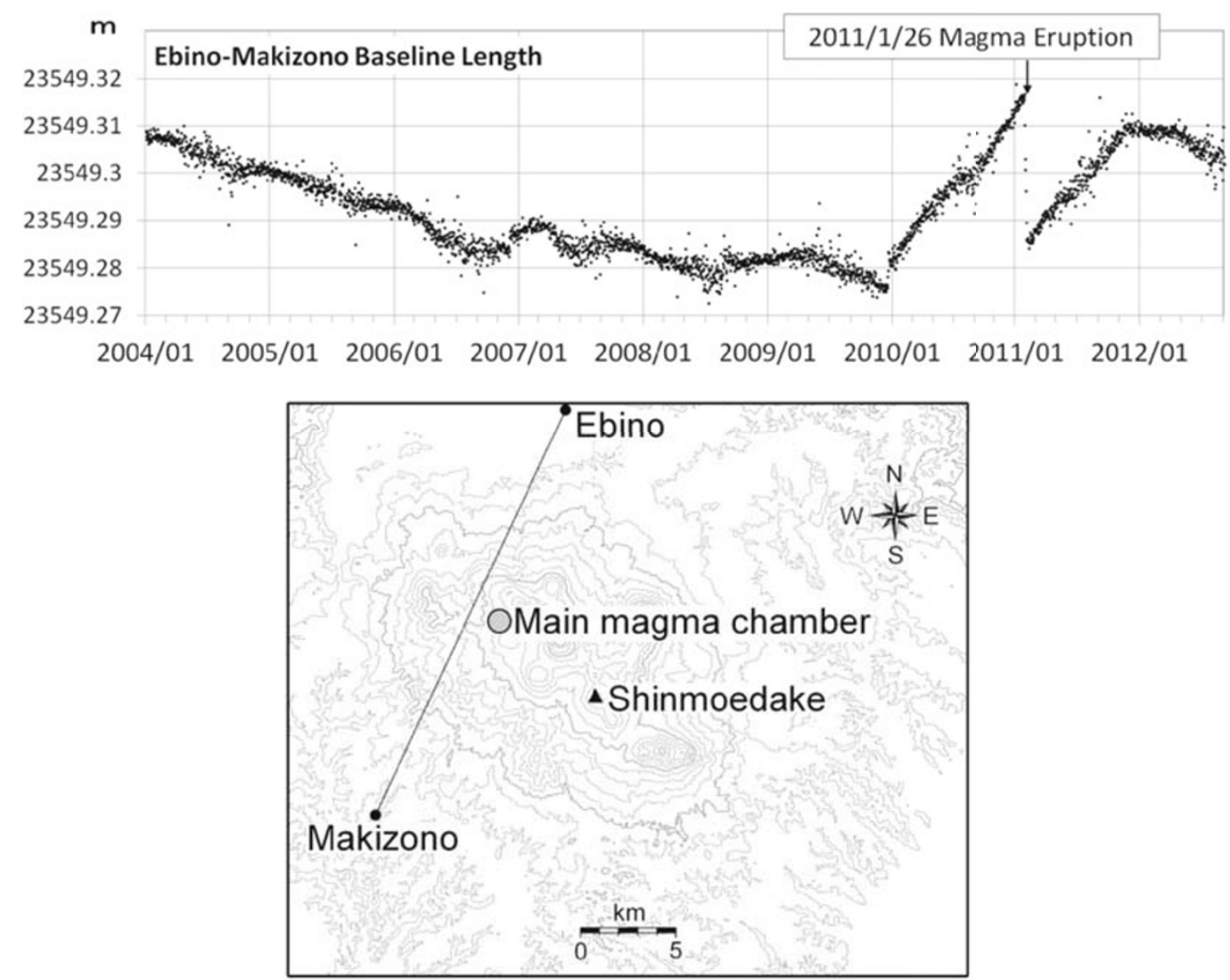

Fig. 9. Temporal change of EBINO-MAKIZONO GNSS baseline installed by Geospatial Information Authority of Japan (top) and GNSS site (bottom).

Table 2. Time sequence of Shinmoedake Volcanic Alert Level.

\begin{tabular}{|c|c|c|}
\hline Date & $\begin{array}{l}\text { Volcanic Alert Level } \\
\text { (Applied area) }\end{array}$ & Factors of level changes \\
\hline $2007 / 12 / 1$ & Level 1 & Strat of Volcanic Alert Level system in Japan \\
\hline $2008 / 8 / 22$ & Level 2 & Small phreatic event occurred. \\
\hline $2008 / 10 / 29$ & Level 1 & Volcanic activity became calm. \\
\hline $2010 / 3 / 30$ & Level 2 & Small phreatic event occurred. \\
\hline $2010 / 4 / 16$ & Level 1 & Volcanic activity became calm. \\
\hline $2010 / 5 / 6$ & Level 2 & Volcanic earthquakes increased. \\
\hline $2011 / 1 / 26$ & Level 3 (2 km) & Subplinian event occurred. \\
\hline $2011 / 1 / 31$ & Level $3(3 \mathrm{~km})$ & $\begin{array}{l}\text { Vigorous growth of lava dome, increasing possibility } \\
\text { of pyroclastic flow by its blowoff. }\end{array}$ \\
\hline $2011 / 2 / 1$ & Level $3(4 \mathrm{~km})$ & $\begin{array}{l}\text { A vulcanian event occurred; ballistic bombs reached } 3.2 \mathrm{~km} \\
\text { from the crater. }\end{array}$ \\
\hline $2011 / 3 / 22$ & Level $3(3 \mathrm{~km})$ & $\begin{array}{l}\text { Frequency and magnitude of eruptive events became lower } \\
\text { than those during January-February. }\end{array}$ \\
\hline $2012 / 6 / 26$ & Level 3 (2 km) & Seismic returned into the activity level before 2011 . \\
\hline
\end{tabular}

levels are associated with the protective actions against the phenomena (see Appendix). The Volcanic Alert Level of Shinmoedake was 1 (normal) in December 2007 (Table 2). JMA raised it from 1 to 2 on 22 August 2008, when a small phreatic eruption event occurred. As the volcanic activity declined after the event, the Volcanic Alert Level was downgraded from 2 to 1 on 29 October 2008.

JMA raised the Volcanic Alert Level from 1 to 2 on 30 March 2010, when a small phreatic eruption event occurred. In response, local governments around Shinmoedake set the areas of access restriction near the crater. After that,
JMA kept the Volcanic Alert Level in 2, because small eruptive events occurred intermittently until July 2010 and the seismic activity remained in a high level.

The first subplinian event occurred at 14:49 on 26 January 2011. In response to this event, JMA raised the Volcanic Alert Level from 2 to 3 and expanded the target area with the distance from 1 to $2 \mathrm{~km}$ from the crater rim at 18:00 on 26 January. Local governments around Shinmoedake took emergency response measures such as setting up emergency operation centers.

On 30 January when the diameter of lava dome was con- 
(a)

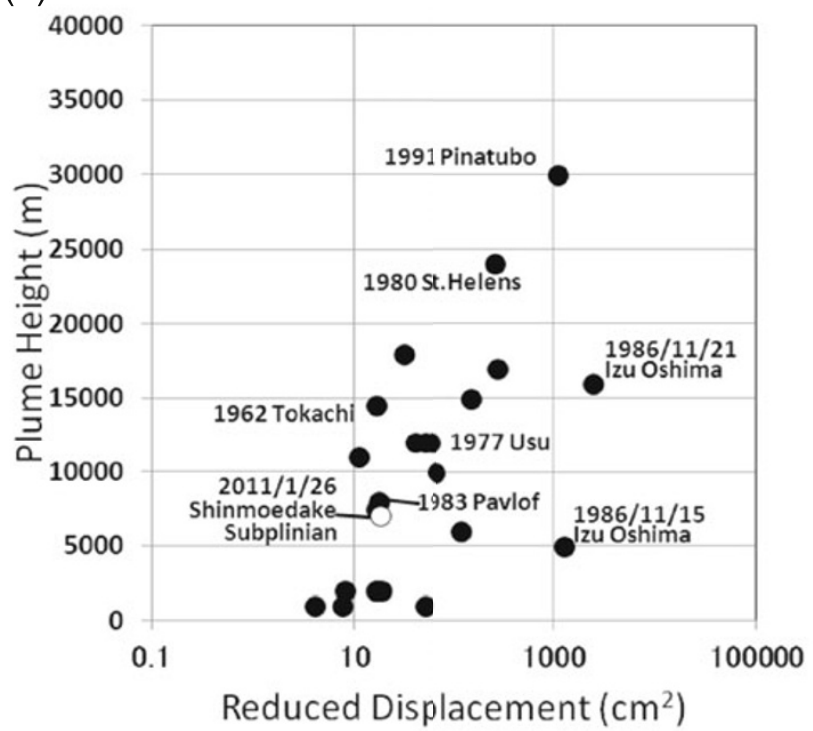

(b)

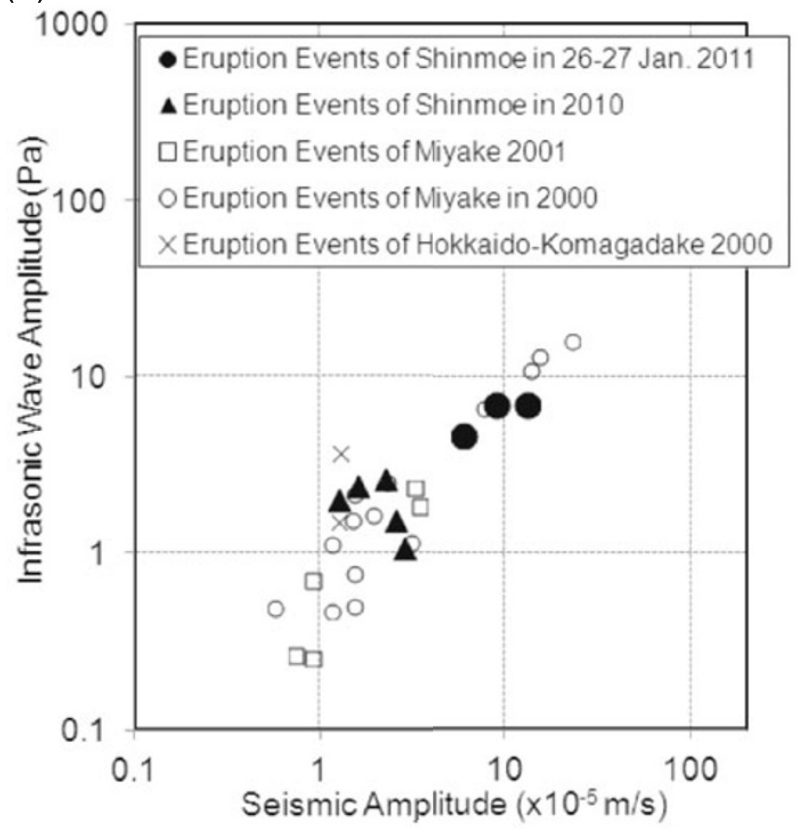

Fig. 10. (a) Reduced displacement of volcanic tremor versus volcanic plume height. Reduced displacement (Aki and Koyanagi, 1981) corresponds to represented amplitude. Except for 2011 Shinmoedake, data are from McNutt (1994). The open circles represent the January 26 Shinmoedake subplinian eruption event. (b) Relationship between seismic and infrasonic amplitude associated with continuous eruptions at recent various volcanoes in Japan. Seismic and infrasonic amplitudes are represented by those at a distance of $3 \mathrm{~km}$ and $5 \mathrm{~km}$ from the active crater, respectively.

firmed to be about $500 \mathrm{~m}$ using a SAR image, analyzed by the Meteorological Research Institute of JMA, a Volcanic Warning was issued at 01:35 on 31 January 2011, and the target area enlarged from 2 to $3 \mathrm{~km}$ from the crater while keeping the Volcanic Alert Level at 3. This was because of the possibility of pyroclastic flows and surges caused by demolition of the lava dome if an eruption event were to occur. In response, local governments prohibited access to the volcano in the area with about $3 \mathrm{~km}$ from the crater. Small resorts of hot spring and prefectural roads within the area 3 $\mathrm{km}$ from the crater were closed by local government. One of local governments, Takaharu Town in Miyazaki Prefecture, which is so close to the crater that residents were able to listen to terrible rumbling and to have received deposition of a large amount of tephra, issued the evacuation advisory on their own judgment. About 600 residents who lived within the area up to $9 \mathrm{~km}$ east of the crater were moved to the evacuation center located about $10 \mathrm{~km}$ from the crater.

At 07:54 on 1 February, a vulcanian event, the fourth event (counting from the first event on 27 January) occurred and ballistic bombs reached about $3 \mathrm{~km}$ west from the crater. JMA issued the Volcanic Warning at 11:20, February 2011, and enlarged the target area from 3 to $4 \mathrm{~km}$ from the crater, keeping the Volcanic Alert Level at 3. Soon after, local government expanded the restricted area to about $4 \mathrm{~km}$ from the crater, and the prefectural road Route 1 , connecting Miyazaki and Kagoshima prefectures, was closed.

On late March 2011, the frequency and magnitude of the eruption events decreased. JMA reduced the target area from 4 to $3 \mathrm{~km}$ from the crater on 22 March 2011, keeping the Volcanic Alert Level at 3. The prefectural road Route 1 was opened by the local government, reflecting reduction of the target area.

Seismicity returned to the level before 2011 and the geodetic monitoring by tiltmeters indicated no additional intrusion of magma beneath Shinmoedake in May 2012. JMA reduced the target area from 3 to $2 \mathrm{~km}$ from the crater on 26 June 2012, keeping the Volcanic Alert Level at 3. In response, the local governments made the area of $3 \mathrm{~km}$ from the crater accessible and hot spring resorts resumed their business.

\section{Discussion and Interpretation of Shinmoedake Magmatic System}

During the lava dome growth in the 2011 eruption, many BL-type earthquakes, harmonic earthquakes and tremors were observed (Fig. 8). BL-type earthquakes which are common at andesitic volcanoes (e.g. Iguchi and Ishihara, 1990) were accompanied by small infrasonic pulses. In the case of Sakurajima volcano, BL-type earthquake swarms, being accompanied by harmonic tremor, were often observed before explosive eruptions (Maryanto et al., 2005). At Shinmoedake, harmonic tremor episodes occurred from 30 January to the beginning of February. The durations of tremor episodes were several minutes to several tens of minutes. The tremor had regular peaks of spectra, composed of a fundamental frequency $(\sim 1 \mathrm{~Hz})$ and its overtones. Like BL-type earthquakes, harmonic tremor is often observed at andesite volcanoes, such as Asama and Sakurajima (e.g. Tameguri et al., 2005). With regard to Sakurajima, Tameguri et al. (2005) suggested that harmonic tremors were related to periodic volume changes caused by the resonance of a gas pocket formed at the top of magma-filled and pressurized conduit. We suggest a similar interpretation of BL-type earthquake and harmonic tremor at Shinmoedake.

During the 2011 activity of Shinmoedake, assignment of Volcanic Alert Levels by JMA was challenging because of the lack of clear precursors before the onset of subplinian events or other vulcanian events. On the other hand, after the beginning of February, tilt changes accompanying 


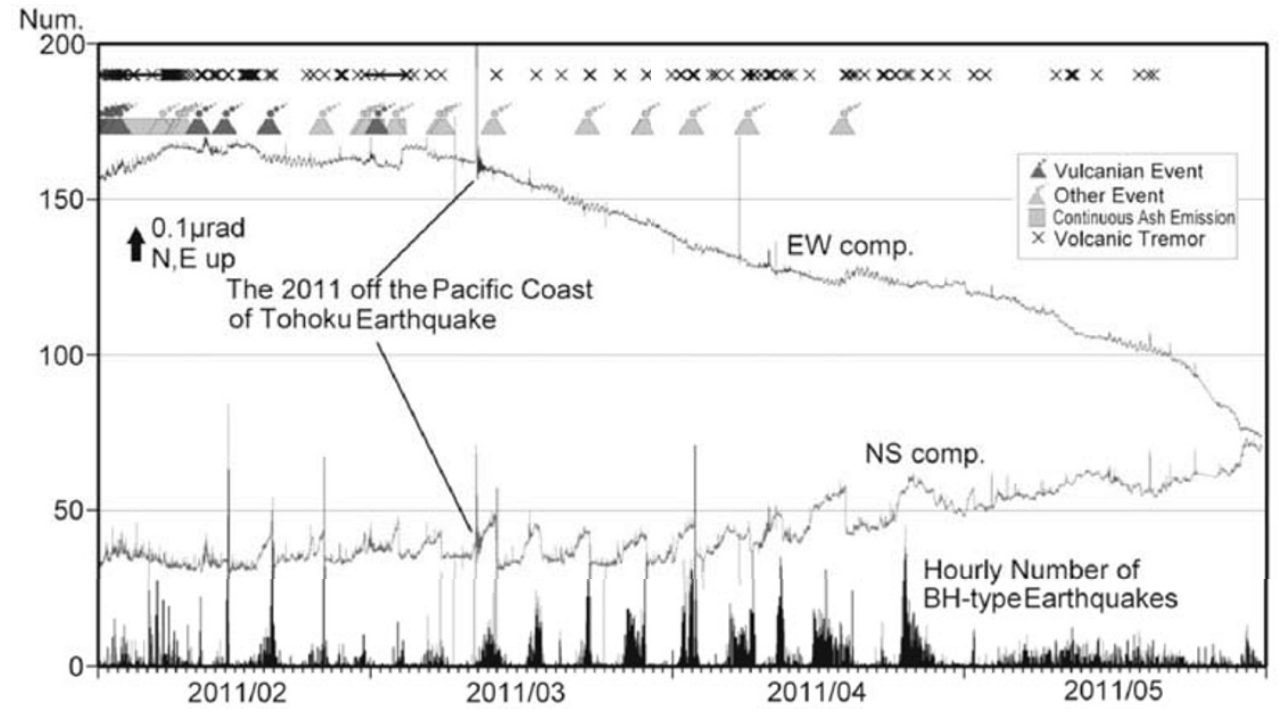

Fig. 11. Tilt records of TCG and hourly number of BH-type earthquakes. Tilt records are corrected to remove tidal effects by BAYTAP-G (Ishiguro and Tamura, 1985).

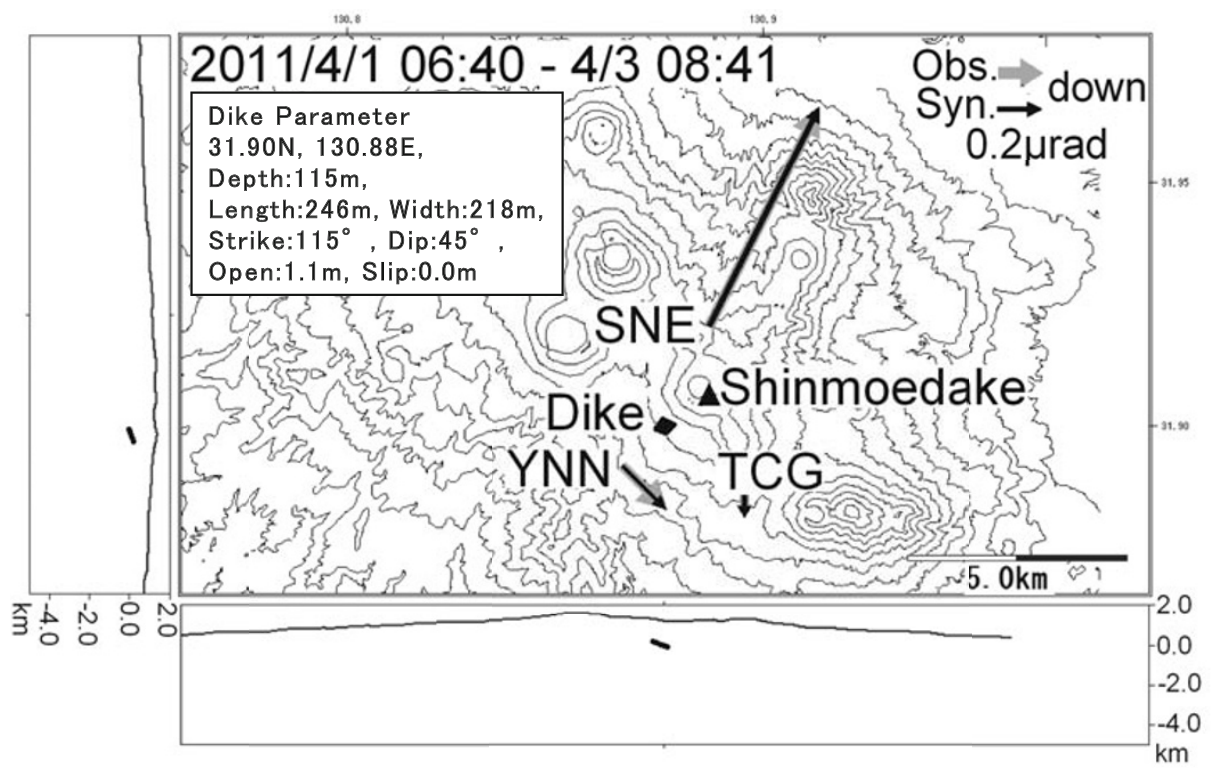

Fig. 12. Observed and synthetic tilt change vectors prior to the eruption event of Shinmoedake on 3 April 2011. Synthetic tilt changes were calculated using a dike model (Okada, 1992).

BH-type earthquake swarms were often observed up to 60 hours prior to the individual eruption events. This result suggests that the prediction of occurrence of eruption events may be possible for Shinmoedake eruption. At some volcanoes, similar tilt changes are observed just before eruptions, as follows. The inflation and deflation tilt patterns have been clearly detected for individual effusive events of the Kilauea volcano, which has a very large eruption rate (Johnson, 1987). At Asama volcano, inflation tilt changes were observed prior to the eruptions in 2004 (Churei and Katayama, 2006). Tilt and strain changes associated with a vulcanian event at Sakurajima volcano (Iguchi et al., 2008). Iguchi et al. (2008) explained the process of precursory signal and eruption as follows: (1) pressure and volume increase during inflation caused by intrusion of magma and accumulation of volcanic gas in the conduit, and (2) pres- sure and volume decrease during deflation as magma and gas are erupted. We suggest that similar process was occurred at Shinmoedake.

Though tilt changes prior to the subplinian event on January 26 were subtle to non-existent, small tilt changes on 18 and 26 January prior to magma eruption events were observed (Fig. 6). Kato and Fujiwara (2012) point out that the both tilt changes were similar to those observed prior to individual events that occurred after the beginning of February. The tilt change vectors on 18 and 26 January were also similar to those after the beginning of February. These observations suggest common deformation sources among those eruption events. Kato and Fujiwara (2012) estimated the total volume changes on 18 and 26 January in orders of $10^{4}$ to $10^{5} \mathrm{~m}^{3}$. The volume of deflation of the deep magma chamber during subplinian events and lava dome growth 


\section{Shinmoedake Eruptive Activity}

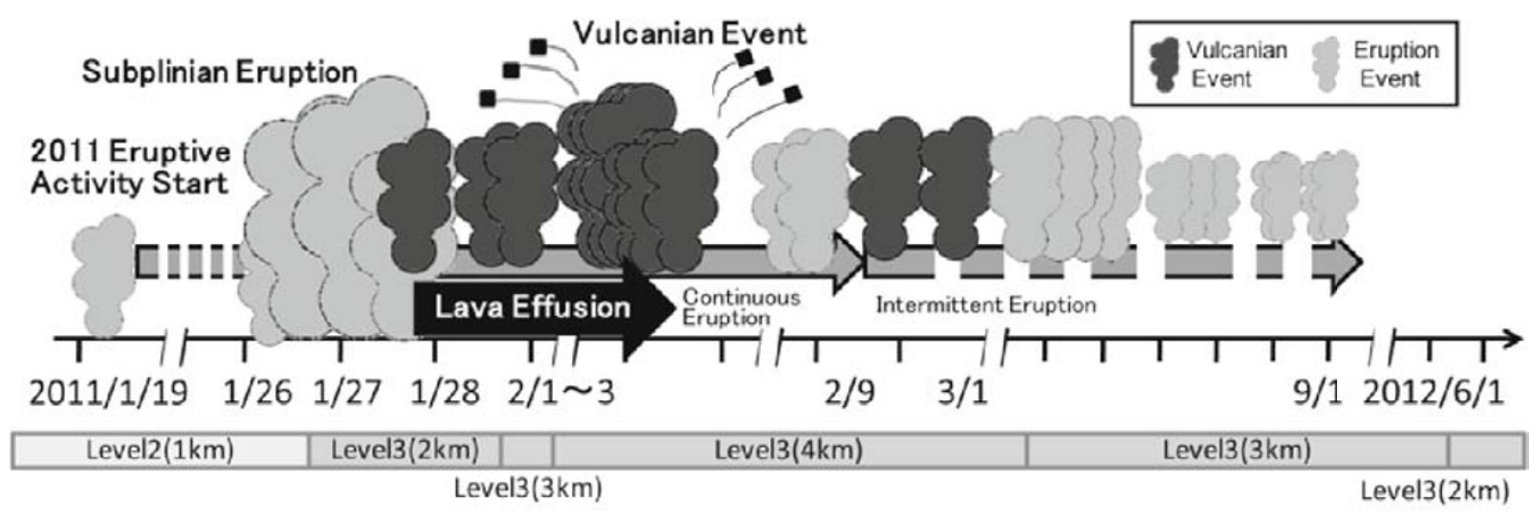

Fig. 13. Schematic illustration of 2011 Shinmoedake eruptive activity.

was estimated as about $10^{7} \mathrm{~m}^{3}$ (Kozono et al., 2013). It is in two orders larger than the inflation volume prior to 18 and 26 January events, and is similar to the ejecta volume from 26 January to the beginning of February.

Figure 5 shows that the volcanic tremor, the infrasound and the tilt change coincided with the start of the subplinian event on 26 January. According to tiltmeter observation, deflation of the deep magma chamber is thought to have started at 16:00, preceded by the increase of seismic and air wave amplitudes at 14:49. These results may suggest that a large amount of magma started to move from the deep magma chamber to beneath the summit crater at around 16:00. The eruption between 14:49 and 16:00 were caused by the magma which once had intruded into the shallow region beneath Shinmoedake prior to the subplinian event. As little magma moved toward Shinmoedake until the subplinian event started, it was difficult to forecast the onset of subplinian event with a sufficient leading time. Therefore, JMA had to issue the Volcanic Alert Level based on the visual observation of the eruptive phenomenon. Despite the delay of Volcanic Alert Level, local governments and residents could prevent any loss of life or injury. To improve the accuracy and timeliness of future alerts at Shinmoedake, JMA installed additional observation stations in the northwestern part of Shinmoedake. Through this improvement, it is expected that JMA will have better sensitivity to discern changes in magma plumbing and movement that may lead to eruption; this should allow issuing of timely alerts. In addition, during the 2011 Shinmoedake eruptive activity, deflation of magma chamber, caused by the subplinian events and lava dome growth, was observed by tiltmeter (Fig. 5) and GPS (Kozono et al., 2013), which enabled us to evaluate the location and volume of magma and was useful to detect magma movement by geodetic observations.

\section{Conclusion}

Figure 13 shows a schematic illustration of the 2011 Shinmoedake eruptive activity. Following repeated phreatic eruption events during 2008-2010, Shinmoedake started magmatic eruption events. Juvenile materials found in volcanic ash on 19 January 2011 suggested the arrival of new magma from the deep magma chamber located northwest of Shinmoedake. The eruptive activity escalated into the subplinian phase on 26 January. Three subplinian events occurred by the evening of 27 January. Soon after that, lava effusion began to fill the summit crater. Vulcanian events started in the evening of 27 January with the strongest event on 1 February.

During the 2011 eruption, a large amount of ash by the subplinian events damaged habitation areas around Shinmoedake. Windows of houses near Shinmoedake were broken by the strong shockwave from the vulcanian event on 1 February. Since then, the eruptive activity decreased with time, though it continued intermittently until September 2011. The seismic activity started to decline in March 2012, and reached the level before the eruption in May 2012.

In response to the 2011 Shinmoedake eruption, JMA issued several Volcanic Warnings and advised local governments to take critical mitigation measures. At the start of the eruptive activity, JMA had set the Volcanic Alert Level as 2 and the local governments prohibited the people to approach near the summit crater. JMA could not issue Volcanic Warnings before the onset of subplinian event due to a lack of clear precursory signals. The Volcanic Alert Level was upgraded by JMA, based on the observation results of eruption phenomena. Integration of geodetic, seismic, and gas flux monitoring made it possible to clarify migration of a large amount of magma from the deep magma chamber, located northwest of Shinmoedake, to the summit crater soon after 26 January subplinian event started. The 2011 eruption at Shinmoedake highlighted the importance of detection and interpretation of magma migration in order to issue timely warnings to local people and governments in order to mitigate risks from volcanic phenomena.

Acknowledgments. We are deeply grateful to the staff members of Kagoshima Local Meteorological Observatory and Fukuoka District Meteorological Observatory for continuous observations of Shinmoedake. We also received generous support from Dr. Setsuya Nakada, Dr. Alan Linde, Mr. Tetsuyuki Ueyama and Mr. Satoshi Harada who read the manuscript and gave valuable comments. Thanks are also to Dr. Christina Neal of AVO and an anonymous reviewer who gave helpful comments to revise this paper. 


\begin{tabular}{|c|c|c|c|c|}
\hline \multirow{2}{*}{ Target Area } & \multirow{2}{*}{$\begin{array}{l}\text { Level and } \\
\text { Keyword }\end{array}$} & \multicolumn{3}{|c|}{ Explanation } \\
\hline & & Expected Volcanic Activity & $\begin{array}{c}\text { Action to be taken by } \\
\text { Inhabitants }\end{array}$ & $\begin{array}{c}\text { Action to be taken by } \\
\text { Climbers }\end{array}$ \\
\hline \multirow{2}{*}{$\begin{array}{l}\text { Residential } \\
\text { Areas }\end{array}$} & $\begin{array}{l}\text { Level } 5 \\
\text { Evacuate }\end{array}$ & $\begin{array}{l}\text { Eruption that may cause } \\
\text { serious damage in residential } \\
\text { areas, or imminent eruption. }\end{array}$ & $\begin{array}{l}\text { Evacuate from the danger } \\
\text { zone. (Target areas and } \\
\text { evacuation measures are } \\
\text { determined in line with } \\
\text { on-going volcanic activity.) }\end{array}$ & \\
\hline & $\begin{array}{l}\text { Level } 4 \\
\text { Prepare to } \\
\text { evacuate }\end{array}$ & $\begin{array}{l}\text { Possibility or increasing } \\
\text { possibility of eruption that may } \\
\text { cause serious damage in } \\
\text { residential areas. }\end{array}$ & $\begin{array}{l}\text { Prepare to evacuate from } \\
\text { alert areas. Make disabled } \\
\text { persons to evacuate. (Target } \\
\text { areas and evacuation } \\
\text { measures are determined in } \\
\text { line with on-going volcanic } \\
\text { activity.) }\end{array}$ & \\
\hline $\begin{array}{l}\text { Non- } \\
\text { Residential } \\
\text { Areas near the } \\
\text { Crater }\end{array}$ & $\begin{array}{l}\text { Level } 3 \\
\text { Do not } \\
\text { approach the } \\
\text { volcano }\end{array}$ & $\begin{array}{l}\text { Eruption or possibility of } \\
\text { eruption that may severely } \\
\text { affect places near residential } \\
\text { areas (threat to life is possible } \\
\text { in these areas). }\end{array}$ & $\begin{array}{l}\text { Stand by, paying attention to } \\
\text { changes in volcanic activity. } \\
\text { Make disabled persons to } \\
\text { prepare to evacuate in line } \\
\text { with on-going volcanic } \\
\text { activity. }\end{array}$ & $\begin{array}{l}\text { Refrain from entering the } \\
\text { danger zone. (Target areas } \\
\text { are determined in line with } \\
\text { on-going volcanic activity.) }\end{array}$ \\
\hline $\begin{array}{l}\text { Around the } \\
\text { Crater }\end{array}$ & $\begin{array}{l}\text { Level } 2 \\
\text { Do not } \\
\text { approach the } \\
\text { crater }\end{array}$ & $\begin{array}{l}\text { Eruption or possibility of } \\
\text { eruption that may affect areas } \\
\text { near the crater (threat to life is } \\
\text { possible in these areas). }\end{array}$ & Stavocucual & $\begin{array}{l}\text { Refrain from approaching the } \\
\text { crater. } \\
\text { (Target areas around the } \\
\text { crater are determined in line } \\
\text { with on-going volcanic } \\
\text { activity.) }\end{array}$ \\
\hline $\begin{array}{l}\text { Inside the } \\
\text { Crater }\end{array}$ & $\begin{array}{l}\text { Level } 1 \\
\text { Normal }\end{array}$ & $\begin{array}{l}\text { Calm: Volcanic ash emissions } \\
\text { or other related phenomena } \\
\text { may occur in the crater (threat } \\
\text { to life is possible in these } \\
\text { areas). }\end{array}$ & & $\begin{array}{l}\text { No restrictions. (In some } \\
\text { cases, it may be necessary } \\
\text { to refrain from approaching } \\
\text { the crater.) }\end{array}$ \\
\hline
\end{tabular}

Fig. A.1. Volcanic Alert Level in Volcanic Forecasts/Warnings. Note that targeted areas with actions depend on the extent of possible hazards. This table is the generic table for all volcanoes in Japan. Designated areas are described in literature such as regional disaster prevention plans.

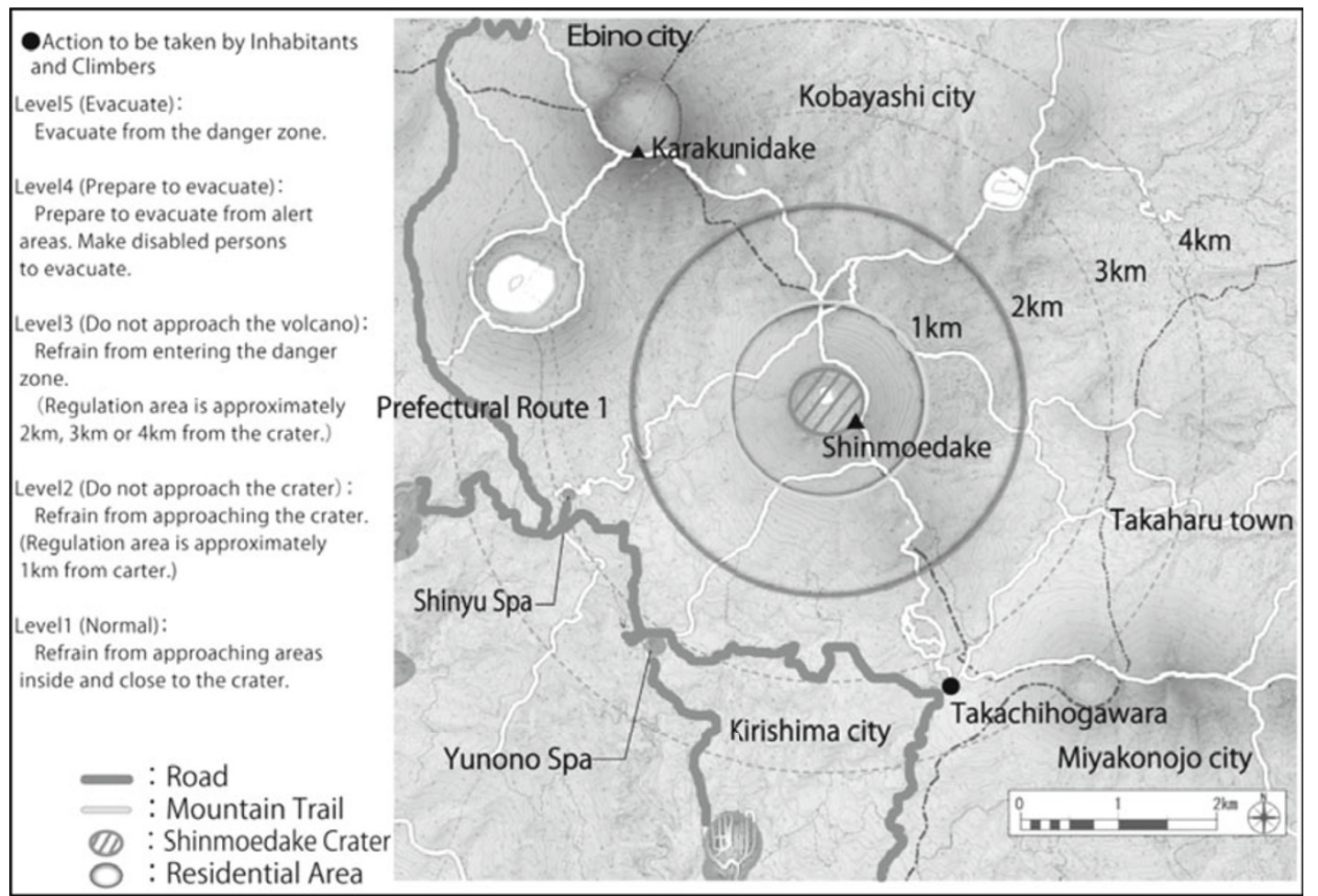

Fig. A.2. Volcanic Alert Level and regulation area of Shinmoedake.

\section{Appendix A. Volcanic Alert Level of JMA}

Japan Meteorological Agency (JMA) began issuing Volcanic Warnings and Volcanic Forecasts on 1 December, 2007 to inform the public and others at risk and minimize the impacts of eruptions. Volcanic Warnings and Volcanic
Forecasts are issued individually for every volcano in Japan, and specify the regions around the volcano where people need to take specific action. Volcanic Warnings are issued to residents through the media, prefectural offices and local municipalities. 
JMA also started issuance of Volcanic Alert Levels. Before the start of Volcanic Warnings, Forecasts, and Alert Levels, JMA had issued 'Volcano Information' during volcanic unrest and eruption emergencies. Although Volcano Information had been also used by local governments to decide disaster countermeasures, the link to the disaster prevention action was regarded as ambiguous. This result urged JMA to develop the current Volcanic Alert Level system. There are five Volcanic Alert Levels based on the disaster mitigation measures required in the target area (Fig. A.1). Volcanic Alert Levels are described with action summary keywords: 'Evacuate', 'Prepare to evacuate', 'Do not approach the volcano', 'Do not approach the crater' and 'Normal', respectively. These descriptions enable residents and climbers to take quick and appropriate action to protect themselves in the event of volcanic unrest or eruption. Volcanic Alert Levels are announced by JMA when issuing Official Volcanic Warnings and Volcanic Forecasts. Volcanic Alert Levels are applied to 29 of the 110 active volcanoes in Japan as of March 2013, and will be applied to other volcanoes when coordination with local municipalities and other related organizations is completed. Specific precautionary actions to be taken in response to Volcanic Alert Levels are described in literature such as the regional disaster prevention plans of municipalities and prefectures.

The Volcanic Alert Level of Shinmoedake applied on 1 December 2007 (Fig. A.2). There is no restriction corresponding to level 1. If JMA issues Volcanic Alert Level 2 , local municipalities should restrict access to within approximately $1 \mathrm{~km}$ of the crater. As for level 3, approaching within approximately $2-4 \mathrm{~km}$ radius from the crater rim is prohibited. When level 4 or 5 is issued, residents must evacuate or prepare for evacuation from the target area. The assigned level is determined based on considering the presumed area where pyroclastic flows, ballistic bombs and lahars may reach. If the area coincides with permanent residents, a decision may be made to evacuate. Though other phenomena such as tephra fall and shock waves are also harmful, it is relatively easy to avoid them by sheltering in place. JMA issued Ash Fall Forecasts when a large eruption (i.e., one with an ash plume height of over 3,000 m above the crater) occurs. These forecasts specify regions in which volcanic ash may fall in approximately 6 hours after the eruption. Therefore, consideration of the impacts of tephra fall and shock waves are not included in the criteria for designating target area.

\section{References}

Aki, K. and R. Y. Koyanagi, Deep volcanic tremor and magma ascent mechanism under Kilauea, Hawaii, J. Geophys. Res., 86, 7095-7110, 1981.

Ando, S., T. Sakurai, Y. Fujiwara, and K. Fukui, The eruption activity in 2011 at Kirishimayama Shinmoedake volcano revealed by ALOS, $A b$ stracts of 2011 Japan Earth Planetary Science Joint Meeting, SVC070P29, 2011.

Churei, M. and H. Katayama, Ground tilt change associated with the 2004 eruption at Asamayama volcano, Japan, Bull. Volcanol. Soc. Jpn., 50, 91-101, 2006 (in Japanese with English abstract).

Geshi, N., S. Takarada, M. Tsutsui, T. Mori, and T. Kobayashi, Products of the August 22, 2008 eruption of Shinmoedake Volcano, Kirishima Volcano Group, Japan, Bull. Volcanol. Soc. Jpn., 55, 53-64, 2010 (in Japanese with English abstract).

Geshi, N., G. Saito, A. Tomiya, I. Miyagi, R. Furukawa, S. Nakano, H.
Hoshizumi, and S. Takarada, Magma of the January 2011 eruption of Shinmoedake, Kirishima volcano, Abstracts of 2011 Japan Earth Planetary Science Joint Meeting, SVC050-04, 2011.

Iguchi, M., A vertical expansion source model for the mechanisms of earthquakes originated in the magma conduit of an Andesitic Volcano: Sakurajima, Japan, Bull. Volcanol. Soc. Jpn., 39, 49-67, 1994.

Iguchi, M. and K. Ishihara, Comparison of earthquakes and air-shocks accompanied with explosive eruptions at Sakurajima and Suwanosejima volcanoes, Annu. Disaster Prev. Res. Inst. Kyoto Univ., 33 B-1, 1-12, 1990 (in Japanese with English abstract).

Iguchi, M., H. Yakiwara, T. Tameguri, M. Hendrasto, and J. Hirabayashi, Mechanism of explosive eruption revealed by geophysical observations at the Sakurajima, Suwanosejima and Semeru volcanoes, J. Volcanol. Geotherm. Res., 178, 1-9, 2008.

Ikeuchi, K. and T. Yokota, Volcanic disaster prevention countermeasures in terms of evacuation systems at eruptions and related phenomena, Abstract of Cities on Volcanoes 5, Shimabara, Japan, 2007.

Imakiire, T. and A. Oowaki, Source model of Kirishima volcano based on GPS integrated analysis in volcanic region, J. Geospat. Inform. Autho. Jpn., 121, 2011 (in Japanese).

Imura, R. and T. Kobayashi, Eruptions of Shinmoedake Volcano, Kirishima Volcano Group, in the last 300 years, Bull. Volcanol. Soc. Jpn., 36, 135-148, 1991 (in Japanese with English abstract).

Ishiguro, M. and Y. Tamura, BAYTAP-G, in TIMSAC-84, Comput. Sci. Monogr., 22, 56-117, 1985.

Johnson, D. J., Dynamics of magma storage in the summit reservoir of Kilauea Volcano, Hawaii, J. Geophys. Res., 97, 1807-1820, 1987.

Kato, K. and Y. Fujiwara, Tilt change preceding the 26 January 2011 magma eruption at Shinmoedake volcano, Abstract of 2012 Fall Meeting Volcanol. Soc. Japan, p. 73, 2012 (in Japanese).

Kato, K., H. Yamasato, T. Koeda, K. Suemine, and S. Matsusue, Eruptions of Shinmoedake volcano in 2010, Abstract of 2010 Fall Meeting Volcanol. Soc. Jpn., p. 147, 2010 (in Japanese).

Kato, K., K. Kokubo, Y. Fujiwara, and S. Matsusue, Tilt change preceding the eruption at Shinmoedake volcano, Abstracts of 2011 Japan Earth Planetary Science Joint Meeting, SVC070-P36, 2011.

Kobayashi, T., Y. Tajima, M. Tsutsui, T. Yamakoshi, and H. Kisa, Precursory eruptions of the 2011 Shinmoedake eruption, Kirishima volcanoes, Japan, Abstracts of 2011 Japan Earth Planetary Science Joint Meeting, SVC070-P06, 2011.

Kozono, T., H. Ueda, T. Ozawa, T. Koyaguchi, E. Fujita, A. Tomiya, and Y. Suzuki, Magma discharge variations during the 2011 eruptions of Shinmoe-dake volcano, Japan, revealed by geodetic and satellite observations, Bull. Volcanol., doi:10.1007/s00445-013-0695-4, 2013 (in press).

Maeno, F., S. Nakada, M. Nagai, and T. Kozono, Ballistic ejecta and eruption condition of the vulcanian explosion of Shinmoedake volcano, Kyushu, Japan on 1 February, 2011, Earth Planets Space, 65, this issue, 609-621, doi:10.5047/eps.2013.03.004, 2013.

Maryanto, S., M. Iguchi, and T. Tameguri, Spatio-temporal characteristics on spectra and particle motion of harmonic tremors at Sakurajima Volcano, Japan, Ann. Disas. Prev. Res. Inst., Kyoto Univ., 48B, 2005.

McNutt, S. R., Volcanic tremor amplitude correlated with the volcanic explosivity index and its potential use in determining ash hazards to aviation, Acta Vulcanol., 5, 193-196, 1994.

Mori, T. and Kagoshima Local Meteorological Observatory, Sulfer dioxide flux of Shinmoedake 2011 eruption, Abstracts of 2011 Japan Earth Planetary Science Joint Meeting, SVC070-P14, 2011.

Mori, T., J. Hirabayashi, K. Kazahaya, T. Mori, M. Ohwada, M. Miyashita, H. Iino, and Y. Nakahori, A compact ultraviolet spectrometer system (COMPUSS) for monitoring volcanic $\mathrm{SO}_{2}$ emission: Validation and preliminary observation, Bull. Volcanol. Soc. Jpn., 52, 105-112, 2007.

Nakada, S., M. Nagai, T. Kaneko, Y. Suzuki, and F. Maeno, The outline of the 2011 eruption at Shinmoe-dake (Kirishima), Japan, Earth Planets Space, 65, this issue, 475-488, doi:10.5047/eps.2013.03.016, 2013.

Okada, Y., Internal deformation due to shear and tensile faults in a halfspace, Bull. Seismol. Soc. Am., 82, 1018-1040, 1992.

Sasaki, H., K. Isobe, S. Homma, M. Sakagami, S. Mukoyama, S. Nakada, T. Kobayashi, and M. Murakami, Estimation of lava volume using oblique aerial photo in Shinmoedake Volcano, Abstract of 2011 Fall Meeting Volcanol. Soc. Jpn., p. 13, 2011 (in Japanese).

Shimbori, T., T. Sakurai, M. Tahara, and K. Fukui, Observation of eruption clouds with weather radars and meteorological satellites: A case study of the eruption at Shinmoe-dake volcano in 2011, Quart. J. Seismol., submitted (in Japanese with English abstract).

Suzuki, Y., M. Nagai, F. Maeno, A. Yasuda, N. Hokanishi, T. Shimano, 
M. Ichihara, T. Kaneko, and S. Nakada, Precursory activity and evolution of the 2011 eruption of Shinmoe-dake in Kirishima volcanoinsights from ash samples, Earth Planets Space, 65, this issue, 591-607, doi:10.5047/eps.2013.02.004, 2013.

Takagi, A., K. Fukui, S. Onizawa, T. Yamamoto, K. Kato, S. Chikazawa, K. Fujiwara, and T. Sakai, Ground deformation around the summit crater before the 2011 Shinmoedake eruption, Quart. J. Seismol., (submitted) (in Japanese with English abstract).

Tameguri, T., S. Maryanto, and M. Iguchi, Moment tensor analyses of harmonic tremors at Sakurajima volcano, Ann. Disaster Prev. Res. Int. Kyoto Univ., 48B, 2005 (in Japanese with English abstract).

Yamasato, H., T. Sakai, and K. Kato, Intensity of volcanic eruption estimated from infrasonic and seismic waves, Abstracts of 2008 Japan Earth Planetary Science Joint Meeting, V151-P026, 2008.

K. Kato (e-mail: koji-kato@met.kishou.go.jp) and H. Yamasato 